\title{
The Effectiveness of Using Online Learning Methods Based on Video Conference in the Course of an Introduction to Microeconomics
}

\author{
Akmal Huda Nasution ${ }^{1}$, Faisal Rahman Dongoran ${ }^{1, *}$, Johnson $^{1}$, Dedy Husrizal Syah ${ }^{1}$ \\ ${ }^{1}$ Universitas Negeri Medan \\ ${ }^{*}$ Corresponding author. Email: frdongoran@ gmail.com
}

\begin{abstract}
The purpose of this study was to investigate the effectiveness of online learning methods based on video conferencing compared to non-video online learning methods in the Microeconomics Management course in the Faculty of Economics, State University of Medan. This research method uses experimental research using the Pre-Test and Post Test questions. There are two classes in this research, namely the learning of experiment class using video conference media and the learning of control class that is only using e-learning web. The population in this study were all faculty of economic in the State University of Medan students who took introductory courses in microeconomics which consisted of 2 classes with a total of 70 students. The number of samples in this study were 70 students, from this study concluded that the control class had an average post-test score of $42.2 \%$, when compared to the results of the post-test scores of the experimental class increased after receiving treatment of using a media learning based on video conference, which has an average value of $64.5 \%$. It can be concluded that online learning media based on video conferencing are more effective in learning.
\end{abstract}

Keywords: Video Conference, Effectivity, Learning Media

\section{INTRODUCTION}

It cannot be denied that the developments and technological advances that have occurred have affected various aspects of life. Likewise, in the aspect of science, especially in the world of education, every educational activity is required to immediately make various improvements and adjustments in every learning process that is carried out. All elements related to the learning process (teaching staff, students, and curriculum) must work together and take advantage of existing technology. Therefore, how the teaching and learning process can run well in this digitalization era, it is necessary to believe that the implementation of the interaction between and students in every learning activity, both in terms of using learning materials, teaching materials (modules) and media as well as existing facilities and infrastructure.

One of elements that are very important in supporting the implementation of the process and the achievement of learning objectives in the current era of technology is the media, in the form of tools and materials used in the learning process. [1] states that learning media is a tool that has functions and can be used to convey learning messages. Sanaky's statement provides an understanding that various forms of communication built in the learning process will be difficult to run properly without the support of means (media) in the process of conveying messages (learning materials). This is confirmed by [2], who argues that media is something that can convey and transmit messages from sources in a planned manner to create a conducive learning environment where the recipient can carry out the learning process efficiently and effectively.

Video conference is one type of interactive telecommunication device that is currently widely used in the learning process in today's digital era. This media allows two or more parties (teaching staff and students) who are in different locations to interact by sending twoway audio and video simultaneously [3]. This is a perfect form of technological advancement (internet). The presence of video conference technology as a medium that can be utilized in the learning process is of course, also an alternative solution to keep the learning process in place in the current Covid-19 pandemic situation. Distance and time are no longer an obstacle, and the learning process can still be carried out even if indirectly. This learning is called Online Learning or Distance Learning Methods. 
The use of video conference technology has been applied in various work activities in the industrial world since the beginning of the industrial revolution 4.0 era. However, its use in the world of education and learning is massive in line with the Covid-19 outbreak, which began to hit since the end of 2019 and continues until now. As a result of the Covid-19 pandemic situation, and to ensure that the learning process is maintained, an internal-based learning approach must be carried out called e-learning in which there are various features to replace and facilitate the learning process that has been carried out face-to-face (directly).

E-learning can be defined as the use of electronic technology to convey various educational and training information, monitor learning activities and report their progress [4]. This approach is used to deliver electronically mediated, well-designed, learner-centred and environmentally interactive learning to anyone, at any time by utilizing the internet and digital technology related to learning design principles [5]. Therefore, educators hope that by utilizing internet technology (elearning) in learning during the Covid-19 pandemic, it will provide facilities for teachers (lecturers) in carrying out their duties as well as for students in activities learn it. This has encouraged every educational institution, especially universities to take part in elaborating technology in educational policies, planning and curriculum $[6,7]$.

The current reality shows that various activities in our life have been integrated and carried out online as well as various learning activities. Lecturers and students have widely used the use of internet technology such as websites (e-learning) in universities. Several factors are why internet-based learning (website) is carried out in addition to the Covid-19 pandemic factor which is currently endemic, it is also influenced by the low cost of using internet access in the field of education, it can even be said to be free [8]. Thus, the use of E-learning in the learning process is a new pattern in the education world today, which is applied to follow up the dynamics of changing times that are so fast both technically and scientifically. Currently, the application of E-learning has become one of the most critical elements of the educational environment in the information era [9]. Elearning is also an innovation learning that is mediated electronically, well designed, student-centred and can be used anywhere, anytime and with anyone [10].

The increasing of internet uses in learning has highlighted to explore thoroughly further a need for technology using. In these current technological advances have paved the way for more creative teaching methods. Therefore, teachers (lecturers) must continuously reconsider their teaching techniques [11]. Innovative use of technology will create techniques that are more effective in distributing learning in nontraditional ways.

In several previous studies, it was stated that elearning is still controversial. In several studies, it is stated that e-learning can produce better teaching and learning than conventional learning [12], and several other studies which state that there is no effect of differences between e-learning and conventional learning [13];[14]. Therefore, the author intends to re-examine the effectiveness of e-learning, especially in the Introduction to Microeconomics class. Educators and students consider this Introductory Microeconomics class as a gateway to the Department of Economics (education and non-education) as well as the economics profession also admit that this course has a high level of difficulty in understanding it.

The challenge that was first highlighted in this introductory macroeconomics course was the need to apply information technology. Current technological developments for higher education are predicted to be very important to ensure the quality of online learning in higher education remains the same as conventional of face-to-face learning [15]. The relationship between the application of technology in the classroom and actual learning is significant. Likewise, for colleges/universities to find out to what extent students can understand technology in their learning, how they use technology, and what they think about technology. This is also in line with the current conditions of the COVID 19 pandemic which are hitting all aspects of life in various parts of the world, and triggering the government to issue educational policies and call for online learning in the world of education.

\section{METHOD}

This research is a quasi-experimental research. A Quasi-Experiment research is by giving specific treatment to the research subject in question using a nonequivalent control group design. The subjects studied were divided into two groups, namely the experimental group, which was given treatment using e-learning media based on video conferencing and the control group, which was given treatment using E-learning non-video conference media. The two groups will be taught with the same material, but it has differences in the teaching method. 
Table 1. The Sample of Demographic Information

\begin{tabular}{|l|c|c|l|}
\hline \multicolumn{1}{|c|}{ Group } & Total & Semester & \multicolumn{1}{|l|}{ Learning Method } \\
\hline Experiment & 34 & III & $\begin{array}{l}\text { ELearning Video } \\
\text { Conference }\end{array}$ \\
\hline Control & 36 & III & $\begin{array}{l}\text { eLearning Non Video } \\
\text { Conference }\end{array}$ \\
\hline Total & 70 & & \\
\hline
\end{tabular}

The sample consisted of 70 students in the Introduction to Microeconomics class, divided into two groups: the experimental group consisted of 34 students, and the control group consisted of 36 students. The independent variable in this study is the learning method, namely: (i) video conference-based learning and (ii) nonvideo conference learning. The dependent variable is the student's post-test results from the two groups. Table 1 . shows the demographic information of students for the odd semester in 2020/2021.

\section{RESULTS AND DISCUSSION}

Based on the descriptive results from the table 4.1, it is known that the average value for pre-test-experimental result data is 45.15 , and the average value for the post-

Table 4. Paired Sample Test

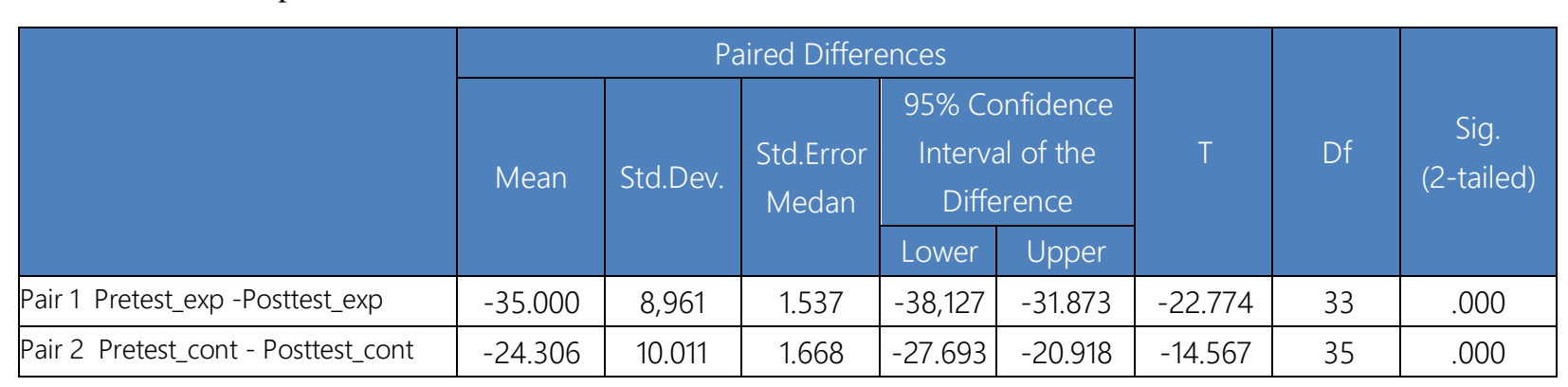

test is 80.15 . While the mean pre-test control class or pretest_control mean score was 41.94 and the post-test means the score was 66.25 . The average value in the control class and the experimental class shows descriptively that there is a difference between average pretest and post-test results.

Based on the output table 4.2 , it is known that the significance value for all data in the KolmogorovSmirnov test $>0.05$, it can be concluded that the research data is normally distributed because the research data is normally distributed. We can use parametric statistics (paired-sample t-test. and independent-sample t-test) to analyze research data.

Based on the output table 4.3 pair1, the sig value obtained is (2-tailed) of $0.000<0,05$. So it can be concluded that there is a difference between the average student test results for the pre-test experimental group and the post-test experimental group (video conference learning).
Table 2. Descriptive Statistic

\begin{tabular}{|l|c|c|c|c|c|}
\hline & $\mathrm{N}$ & Min & Max & Mean & Std.Dev \\
\hline $\begin{array}{l}\text { Pretest } \\
\text { Experiment }\end{array}$ & 34 & 30 & 60 & 45.15 & 9.652 \\
\hline $\begin{array}{l}\text { Posttest } \\
\text { Experiment }\end{array}$ & 34 & 65 & 95 & 80.15 & 9.414 \\
\hline $\begin{array}{l}\text { Prestest } \\
\text { Control }\end{array}$ & 36 & 25 & 60 & 41.94 & 11.230 \\
\hline $\begin{array}{l}\text { Posttest } \\
\text { Control }\end{array}$ & 36 & 50 & 85 & 66.25 & 11.488 \\
\hline $\begin{array}{l}\text { Valid N } \\
\text { (listwise) }\end{array}$ & 34 & & & & \\
\hline
\end{tabular}

Table 3. Test of Normality

\begin{tabular}{|c|c|c|c|c|c|c|}
\hline Group & \multicolumn{3}{|c|}{$\begin{array}{l}\text { Kolmogorov } \\
\text { Smirnov² }\end{array}$} & \multicolumn{3}{|c|}{ Shapiro-Wilk } \\
\hline \multicolumn{7}{|l|}{ Skoring: } \\
\hline Pretest_exp & .118 & 34 & $200^{*}$ & .932 & 34 & .035 \\
\hline Posttest_exp & .124 & 34 & $.200^{*}$ & .935 & 34 & .044 \\
\hline Pretest_cont & .121 & 36 & $200^{*}$ & .936 & 36 & .038 \\
\hline Posttest_cont & .123 & 36 & .182 & .928 & 36 & .022 \\
\hline
\end{tabular}

$*$ This is a lower bound of the true significance. a. Liliefors Significance Correction 
Table 6. Independent Samples Test

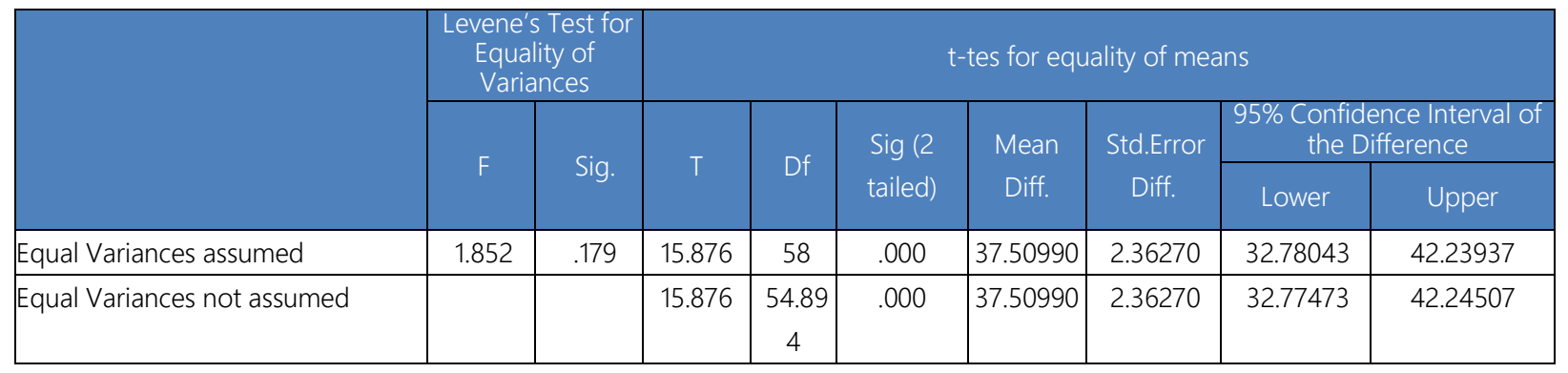

Based on the output table 4.4 of the homogeneity test results above, it is known that the significance value (sig) Based on Mean is $0.153>0.05$, so it can be concluded that the variance of the post-test group of the experimental group and the post-test of the control group is same or homogeneous. Thus, one of the requirements

Table 7. n-Gain descriptive

\begin{tabular}{|c|c|c|c|}
\hline \multicolumn{2}{|c|}{ Group } & \multirow{2}{*}{$\begin{array}{r}\text { Statistic } \\
64.5143\end{array}$} & \multirow{2}{*}{$\begin{array}{l}\text { Std.Error } \\
2.71501\end{array}$} \\
\hline & $\begin{array}{l}\text { Mean } \\
\text { 95\% Confidence Interval for } \\
\text { Mean }\end{array}$ & & \\
\hline & Lower Bound & 58.9906 & \\
\hline & Upper Bound & 70.0381 & \\
\hline & 5\% Trimmed Mean & 65.1548 & \\
\hline & Median & 63.6364 & \\
\hline & Variance & 250.623 & \\
\hline & Std.Deviation & 15.83107 & \\
\hline & Minimum & 30.00 & \\
\hline & Maximum & 87.50 & \\
\hline & Range & 57.50 & \\
\hline & Interquartile Range & 23.93 & \\
\hline & Skewness & -.379 & .403 \\
\hline & Kurtosis & -.287 & .788 \\
\hline Cont & $\begin{array}{l}\text { Mean } \\
\text { 95\% Confidence Interval for } \\
\text { Mean }\end{array}$ & 42.1899 & 2.54943 \\
\hline & Lower Bound & 37.0143 & \\
\hline & Upper Bound & 47.3655 & \\
\hline & 5\% Trimmed Mean & 41.7063 & \\
\hline & Median & 41.6667 & \\
\hline & Variance & 233.985 & \\
\hline & Std.Deviation & 15.29655 & \\
\hline & Minimum & 9.09 & \\
\hline & Maximum & 80.00 & \\
\hline & Range & 70.91 & \\
\hline & Interquartile Range & 23.22 & \\
\hline & Skewness & .398 & .393 \\
\hline & Kurtosis & .193 & .768 \\
\hline
\end{tabular}

of the test independent sample t-test has been fulfilled.

Based on the output table 4.5 , the sig value is obtained. (2-tailed) of $0.000<0.05$, it can be concluded that there is a difference in the average student test results between video conference-based learning and non-video conference learning.

Based on the results of the calculation of the N-Gain score test, it shows that the average $\mathrm{N}$-Gain score for the experimental group (video conference method) was 64.5143 or $64.5 \%$ in the quite effective category with a minimum N-Gain score of $30 \%$ and a maximum of $87.50 \%$.

Meanwhile, the average N-Gain score for the control group (non-video conference method) was 42.1899 or $42.2 \%$ in the less effective category, with a minimum $\mathrm{N}$ Gain score of $9.09 \%$ and a maximum of $80 \%$.

So, it can be concluded that the use of video conference-based learning methods is quite effective in improving student abilities in introductory micro economics courses in the Faculty of Economics, State University of Medan. In contrast, the use of non-video conferencing learning methods is ineffective to improve student abilities in introductory microeconomics courses in Environment Faculty of Economics, State University of Medan.

Table 8. Group Statistic

\begin{tabular}{|l|c|c|c|c|}
\hline & $N$ & Mean & Std.Dev & Std.Error Mean \\
\hline n-Gain percent: & & & & \\
\hline Experiment: & 34 & 64.5143 & 15.83107 & 2.71501 \\
\hline Control & 36 & 42.1899 & 15.29655 & 2.54943 \\
\hline
\end{tabular}

Based on the Group Statistics output table 4.7, it is known that the Mean N-Gain percent value for the experimental group is 64.5143 or $64.5 \%$. Based on the category table for the interpretation of the effectiveness of the N-Gain value (\%), it can be concluded that the use of video conference-based learning methods (in the experimental class) is quite effective in improving student abilities.

Furthermore, it is known that the Mean N-Gain percent value for the control class is 42.1899 or $42.2 \%$ so that based on the table of the category of interpretation of the effectiveness of the N-Gain value (\%) it can be concluded that the use of non-video conference learning methods (in the control class) is not effective to improve student abilities.

So, descriptively and statistically, it can be said that there is a difference in the effectiveness of the application of video conference-based learning methods with nonvideo conference learning methods in improving student abilities. 
Based on the output table 4.5, it is known that the sig value in Levene's Test for Equality of Variance is 0.179> 0.05 , so it can be concluded that the N-Gain data variance (\%) for the experimental class and control class data is homogeneous.

Based on the Independent Sample Test output table, it is known that the sig (2-tailed) value is $0,000<0.05$, thus it can be concluded that there is a significant (real) difference in effectiveness between the use of video conference-based and non-video conference learning method in improving student abilities in introductory microeconomics courses in the Faculty of Economics, State University of Medan, Academic Year of Odd Semester 2020/2021.

Learning through video conferencing can not only optimize the direct interaction between students and teachers, but it can also show the learning material on display and can be seen by all participants so that participants not only hear explanations but can also examine the material provided [16]. This is accordance with the results of Putrawangsa and Hasanah's research which states that learning using video conferencing allows for direct interaction between students and educators, but not in the same place [17].

\section{CONCLUSION}

The conclusion obtained in this study that the effectiveness level of e-learning media based on video conferencing on the ability of students on the Introductory Micro Economics Study Program, Economic Faculty, the State University of Medan who take online learning in the experimental class is higher than in the control class using non-video learning media. conference $64.51>42.18$ or $64.5 \%>42.2 \%$. As a followup to the need for the application of learning using elearning media based on video conferencing in improving student abilities.

\section{ACKNOWLEDGMENTS}

This research was funded by the State University of Medan from the Unimed PNBP Basic Research program in 2020.

\section{REFERENCES}

[1] Sanaky, H. A. H., Media Pembelajaran InteraktifInovatif. In Kaukaba Dipantara, 2013

[2] Munadi, Y., Media Pembelajaran (sebuah pendekatan baru). Jakarta: Gaung Persada Press, 2008

[3] Wikipedia. Teknologi Informasi Komunikasi. 30 April 2014.

[4] Wiebe, E., \& Sharek, D., eLearning. In Why Engagement Matters: Cross-Disciplinary
Perspectives of User Engagement in Digital Media. 2016, https://doi.org/10.1007/978-3-319-27446-1_3

[5] Sousa, M. J., \& Rocha, Á., Digital learning: Developing skills for digital transformation of organizations. Future Generation Computer Systems, 2019 , https://doi.org/10.1016/j.future.2018.08.048

[6] Choshin, M., \& Ghaffari, A., An investigation ofthe impact ofeffective factorsonthe success of ecommerce in small- and medium-sized companies. Computers in Human Behavior, 2017 https://doi.org/10.1016/j.chb.2016.09.026

[7] Lim, D. H., \& Morris, M. L., Learner and instructional factors influencing learning outcomes within a blended learning environment. Educational Technology and Society, 2009

[8] Aparicio, M., Bacao, F., \& Oliveira, T., Grit in the path to e-learning success. Computers in Human Behavior, 2017 , https://doi.org/10.1016/j.chb.2016.10.009

[9] Zare, M., Sarikhani, R., Salari, M., \& Mansouri, V., The impact of E-learning on university students' academic achievement and creativity. Journal of Technical Education and Training, 2016.

[10] Ayanda, D. O., Eludiora, S. I., Amassoma, D. J., Ashiru, M. A., \& Ankewusola, M. A., Towards a model of e-learning in Nigerian higher institutions: An evolutionary software modeling approach. Research Journal of Applied Sciences. 2012, https://doi.org/10.3923/rjasci.2012.240.246

[11] Holtzblatt, M., \& Tschakert, N., Expanding your accounting classroom with digital video technology. Journal of Accounting Education, 29(2- 3), 2011 ,

$100-121$ https://doi.org/10.1016/j.jaccedu.2011.10.003

[12] Aurandt, J. L., \& Butler, E. C., Sustainability education: Approaches for incorporating sustainability into the undergraduate curriculum. Journal of Professional Issues in Engineering Education and Practice. 2011 https://doi.org/10.1061/(ASCE)EI.19435541.0000049

[13] Chang, C. C., Shu, K. M., Liang, C., Tseng, J. S., \& Hsu, Y. S., Is blended e-learning as measured by an achievement test and self-assessment better than traditional classroom learning for vocational high school students? International Review of Research in Open and Distance Learning. 2014, https://doi.org/10.19173/irrodl.v15i2.1708.

[14] Elmer, S. J., Carter, K. R., Armga, A. J., \& Carter, J. R., Blended learning within an undergraduate 
exercise physiology laboratory. Advances in Physiology Education, 2016, https://doi.org/10.1152/advan.00144.2015.

[15] Myring, M., Bott, J. P., \& Edwards, R., New Approaches to Online Accounting Education. The CPA Journal, 2014.

[16] Sandiwarno, S., Perancangan Model E-Learning Berbasis Collaborative Video Conference Learning Guna Mendapatkan Hasil Pembelajaran Yang Efektif Dan Efisien. Jurnal Ilmiah FIFO, 8(2), 2016, 191. https://doi.org/10.22441/fifo.v8i2.1314

[17] Putrawangsa, S., \& Hasanah, U., Integrasi Teknologi Digital Dalam Pembelajaran Di Era Industri 4.0. Jurnal Tatsqif, 16(1), $2018 \quad$ 42-54. https://doi.org/10.20414/jtq.v16i1.203 